\title{
RETRACTION
}

\section{miR-661 expression in SNAI1-induced epithelial to mesenchymal transition contributes to breast cancer cell invasion by targeting Nectin-1 and StarD10 messengers}

G Vetter, A Saumet, M Moes, L Vallar, A Le Béchec, C Laurini, M Sabbah, K Arar, C Theillet, C-H Lecellier and E Friederich Oncogene (2016) 35, 670; doi:10.1038/onc.2015.265; published online 14 December 2015

Retraction to: Oncogene (2010) 29, 4436-4448; doi:10.1038/

onc.2010.181; published online 14 June 2010

At the request of the University of Luxembourg and following an external investigation, the Editor and Publisher have agreed to retract this paper owing to unreliable data. 